\title{
The development of a Portuguese mobile application for clinical support in detecting leprosy suspects
}

\author{
Bruna Canci ${ }^{\mathrm{a}}$, Erica Gomes Pereira ${ }^{\mathrm{a}}$, Karen Sakata-So ${ }^{\mathrm{a}}$ \& \\ Lucia Nichiata $^{\mathrm{a}}$

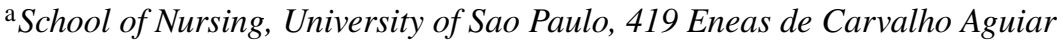 \\ Avenue Sao Paulo/Sao Paulo, 05403-000, Brazil
}

Submitted 7 December 2020; Accepted 18 March 2021

\begin{abstract}
Summary
Objectives: To describe the planning and development of a mobile application for assessing leprosy suspects.

Methods: The technological production was carried out using four of the five phases of the ADDIE model: Analysis, Design, Development, and Implementation from August 2017 to August 2018.

Results: The "Hansen's disease" application integrates images, videos, and text with essential information for the evaluation of dermatoneurological suspects. It is available for free on Play Store and Apple Store, with the possibility of offline handling, and comprises a size of $42.25 \mathrm{MB}$.

Conclusions: The application is expected to support health care professionals in leprosy control actions among the susceptible population and confirmed case communicators to eliminate transmission and achieve Sustainable Development Goal 3health and well-being for all by 2030 .
\end{abstract}

Keywords: Training, sustainable development goals, passive and active case finding

\section{Introduction}

Leprosy is a global public health problem that can generate physical, economic, and social disabilities. The worldwide detection rate between $2017-2018$ was $2.74 / 100,000$ inhabitants. ${ }^{1}$ In this context, regions raking first and second in the percentage of new cases recorded per 100,000 inhabitants are South-East Asia (7.49) and the Americas (3.08). Three countries representing $79.6 \%$ of all the newly diagnosed cases include India, Indonesia, and Brazil. ${ }^{1}$

India and Indonesia contributed $92 \%$ of South-East Asia cases, and Brazil contributed $93 \%$ of the patients in the Americas. ${ }^{1}$ Between 2010 and 2017, new cases in the Americas decreased by $22.5 \%$ (from 37,571 to 29,101 ). ${ }^{2}$ Clinical manifestations can appear from two to seven years

Correspondence to: Dr. Erica Gomes Pereira (e-mail: egpereira@usp.br) 
and, in some cases, even more than ten years from the initial contact with the infectious agent Mycobacterium leprae. ${ }^{3}$

The upper airways are the main form of transmission of the bacteria from close and prolonged contact with susceptible people, especially when living in the same home. ${ }^{4}$ Considering this possible spread at home, the agile screening of symptomatic patients can contribute to the disease transmission chain's control.

The global strategy for the period of 2016-2020 published by the World Health Organization (WHO) is aimed at reducing the global and local burden by early detection before the onset of disabilities and improving actions focused on prevention, development of new diagnostic methods, reduction of stigma and promotion of partnerships with nongovernmental organizations (NGOs), community organizations (CO), among others. ${ }^{5}$

The advancement of mobile technologies is fostering the design of a new era of electronic health or e-Health, which provides support to health services and health care professionals in diagnostic support, patient management, among other communication possibilities for health care professionals making use of these types of service. ${ }^{6}$

In this sense, an application for clinical support in the detection of leprosy suspects enhances the dissemination of information for the early identification of the predictive symptoms of the disease in order to expand control and reduce transmission. The present technological research is justified by improving the early identification of typical leprosy lesions by community health care workers and promoting suspected cases to the health care network. Thus, the present study's objective was to describe the planning and development of a mobile application for clinical support in detecting leprosy suspects in Portuguese-speaking countries.

\section{Methods}

Descriptive, technological production study for developing a multimedia application on a mobile platform, focusing on clinical support for detecting leprosy suspects in Portuguesespeaking countries.

The application was developed between August 2017 and August 2018 from four of the five phases of the Systematic Instructional Design method, also known as the ADDIE model: $:^{7,8}$ Analysis, Design, Development, Implementation and Evaluation. The phases used in this study were: Analysis, Design, Development and Implementation.

The actions taken in each phase of the application were:

(1) Analysis: search for applications related to leprosy in the virtual stores of the Play Store (Android, Google) and App Store (iOS, Apple) operating systems between August and October of 2017, the definition of the trade name- "Hansen's disease", target audienceprofessionals with higher education, self-instructional characteristics-clinical support with essential tests for the examination of suspected cases, rapid applicability in any clinical care and a bibliographic review on the role of health care professionals in the control of leprosy.

(2) Design: selection and presentation strategy of the contents, elaboration of the storyboard using the Knowles andragogical model ${ }^{9}$ and the guidelines of the Global Strategy for Leprosy 2016-2020 of the World Health Organization (WHO).

(3) Development: planning and production of teaching materials, selection of media and design of the interface (layout), selection of technologies necessary for the development of the application, the definition of the navigation structure and planning of the configuration of the environments (HTML, CSS and JavaScript). 
(4) Implementation: definition of the platforms that will be used for handling the tool, configuration of the environment for downloading the application on the internet (Android and $\mathrm{iOS}$ ) and installation on the mobile device.

The Research Ethics Committee approved the School of Nursing study from the University of São Paulo (USP) and the Municipal Health Secretariat of São Paulo (opinions 2490,656/2018 and 2801,729/2018) according to the World Medical Association's Declaration of Helsinki's guidelines.

\section{Results}

\section{LEPROSY APPLICATION ANALYSIS AND DESIGN PROCESS}

Applications were investigated in virtual stores in Portuguese with the words "hanseníase, mal de Hansen, e lepra"; in Spanish "enfermedad de Hansen, e lepra"; and in English "Hansen's disease, and leprosy". Three applications were found for health care professionals with higher education, as described in Figure 1.

It was observed that no application featured clinical support for detecting leprosy suspects neither in the susceptible nor communicating population.

As the main focus, all of them described the defining symptoms of the disease, the different clinical forms, the drug regimens for the treatment, and the monitoring of adverse reactions and sequelae.

Next, the app's trade name-_Hansen's disease" and the colour base-purple, an option from the WHO for educational campaigns to combat leprosy, were defined. The scientific content was then selected, the screen prototype was made, and the technology company that developed the application was defined.

\section{DEVELOPMENT AND IMPLEMENTATION OF HANSEN'S DISEASE APPLICATION}

The application was hosted on the servers of Universidade Estadual Paulista (UNESP) with free access. It was specifically produced for health care professionals in Portuguese available for download on Play Store https://play.google.com/store/apps/details?id=com.ltia.hansenias e\&hl=pt_BR and App Store https://apps.apple.com/br/app/hansen\%C3\%ADase/id14329678 72 ? $=$ en with the possibility of offline handling, with a size of $43.25 \mathrm{MB}$.

A small sample of 47 professional healthcare workers applied the mobile app to the usability test during the lepra pre-campaign in Brazil's metropolis. After reading the example case, the people answer several questions: The mobile app has the main functions to detect leprosy suspects?; It is precise in the operationalization of its functions?; It is easy to learn how to use it in routine work?; It offers help?; The features made available are appropriate?; It has technical errors?. Most of the participants of the pre-campaign agreed to answer the questions about mobile app usability.

The main page includes three sections: "What is leprosy?", "Signs and symptoms" and "What to do in case you suspect leprosy?" (Figure 2).

The first section, "What is leprosy?" consists of brief information about the cause of the disease, the main signs and symptoms, the importance of compulsory notification if the diagnosis is confirmed (required by the Brazilian health authorities), the mandatory epidemiological investigation of household contacts.

The second section, "Signs and symptoms", is divided into two icons: lesions and nerve involvement. Also, images are presented with the textual description of skin lesions of 


\begin{tabular}{|c|c|c|c|c|c|c|}
\hline Application & Platform & Language & Size & Focus & $\begin{array}{l}\text { Creatio } \\
\text { n date }\end{array}$ & Copyright \\
\hline $\begin{array}{l}\text { App1: } \\
\text { SkinApp } \\
\text { NLR }\end{array}$ & $\begin{array}{l}\text { Android } \\
\text { and ios }\end{array}$ & English & $90 \mathrm{MB}$ & $\begin{array}{l}\text { identification of signs / } \\
\text { symptoms, diagnosis } \\
\text { and treatment of the } \\
\text { most prevalent } \\
\text { dermatological diseases }\end{array}$ & $\mathrm{Dec} / 16$ & $\begin{array}{l}\text { Netherlands } \\
\text { Leprosy Relief }\end{array}$ \\
\hline $\begin{array}{l}\text { App2: } \\
\text { SkinApp MZ }\end{array}$ & $\begin{array}{l}\text { Android } \\
\text { and iOS }\end{array}$ & Portuguese & $87 \mathrm{MB}$ & $\begin{array}{l}\text { identification of signs / } \\
\text { symptoms, diagnosis } \\
\text { and treatment of the } \\
\text { most prevalent } \\
\text { dermatological diseases }\end{array}$ & $\begin{array}{l}\text { May/1 } \\
7\end{array}$ & $\begin{array}{l}\text { Netherlands } \\
\text { Leprosy Relief }\end{array}$ \\
\hline $\begin{array}{l}\text { App } 3: \\
\text { Lepra } \\
\text { Reaction } \\
\text { Basic } \\
\text { Management }\end{array}$ & Android & English & $2,34 \mathrm{MB}$ & $\begin{array}{l}\text { classification of drug } \\
\text { reactions and monitoring } \\
\text { the severity of reactions } \\
\text { with feeding from an } \\
\text { image bank per patient } \\
\text { for use by doctors }\end{array}$ & Oct $/ 17$ & $\begin{array}{l}\text { Doctor } \\
\text { Pugazhenthan } \\
\text { Thangaraju/De } \\
\text { partment of } \\
\text { Pharmacology - } \\
\text { All India } \\
\text { Institute of } \\
\text { Medical } \\
\text { Sciences } \\
\text { Raipur }\end{array}$ \\
\hline
\end{tabular}

Source: elaborated and prepared by the authors.

Figure 1. Leprosy-focused apps.

Borderline or dimorphous, Hansen's disease, Paucibacillary (PB), or tuberculoid, Hansen's disease; Multibacillary (MB), or lepromatous, Hansen's disease indeterminate (Figure 3).

The third section, "What to do in case you suspect leprosy?" is subdivided into two icons, namely dermatoneurological examination and referral of a suspected case for diagnostic confirmation at a referral health service. The dermatoneurological exam icon allows the selection of three other icons, namely "eyes", "hands", and "feet". There is a textual description with videos of unchanged findings for priority tests on eyes (closed eyes, decreased corneal sensitivity, visual acuity), hands (muscle strength — open little finger, raise the thumb, raise the wrist; sensitivity — check inspection points) and feet (muscle strength raise hallux, elevate the foot; sensitivity — check inspection points). Figure 4 shows the sequence of the screens that make up the section "What to do in case you suspect leprosy?". 


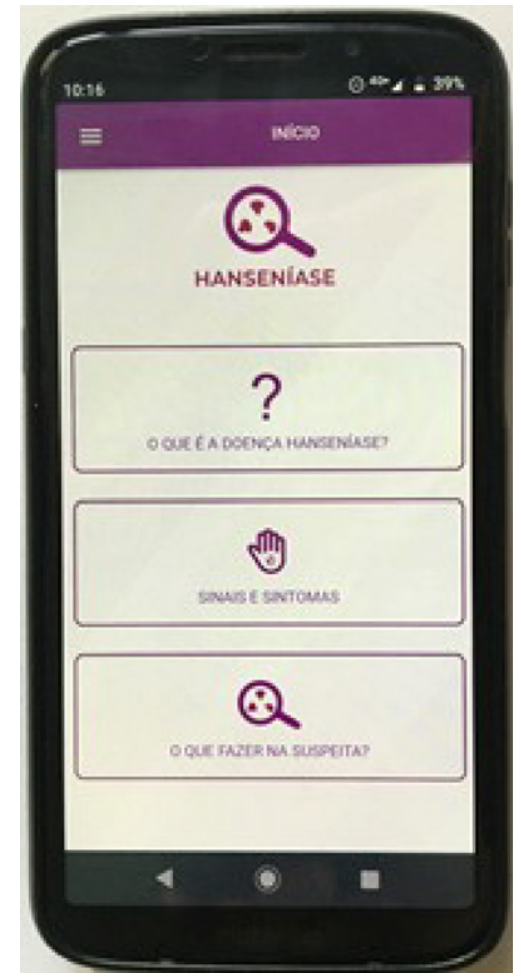

Figure 2. Illustrative image of the central section selection screen.

\section{Discussion}

With the increase in access to mobile technologies nowadays, including the use of these technologies as clinical resources for health care professionals, and considering the epidemiological situation of leprosy in the Americas, especially in Brazil, the idea of an application arose through the possibility of it being able to support health care professionals in the screening and early detection of leprosy.

The rates of smartphone owners have been growing at an accelerated rate in emerging and developing countries, rising from an average of $21 \%$ in 2013 to $37 \%$ in 2015, especially in populated countries such as Brazil, Russia, and China. Among the countries surveyed, the percentage of adults who claimed to own smartphones in 2015 in the Americas was: $72 \%$ in the United States, $67 \%$ in Canada, $65 \%$ in Chile, $48 \%$ in Argentina, $45 \%$ in Venezuela, $41 \%$ in Brazil, 35\% in Mexico, and 25\% in Peru. It is estimated that in 2020 there will be 6 billion smartphone users globally, which represents approximately $80 \%$ of the world population. ${ }^{10,11}$ As for mobile devices, more than 7 billion people were already users at the end of $2015 .^{12}$

All three applications related to leprosy found in the online stores when the "Hansen's disease" application was developed were focused on confirming the diagnosis, the treatment and the monitoring of disabilities already manifested.

Two of them were in English, and one was in Portuguese, this being the reproduction of one of the applications that were already in English. The three applications were created from 


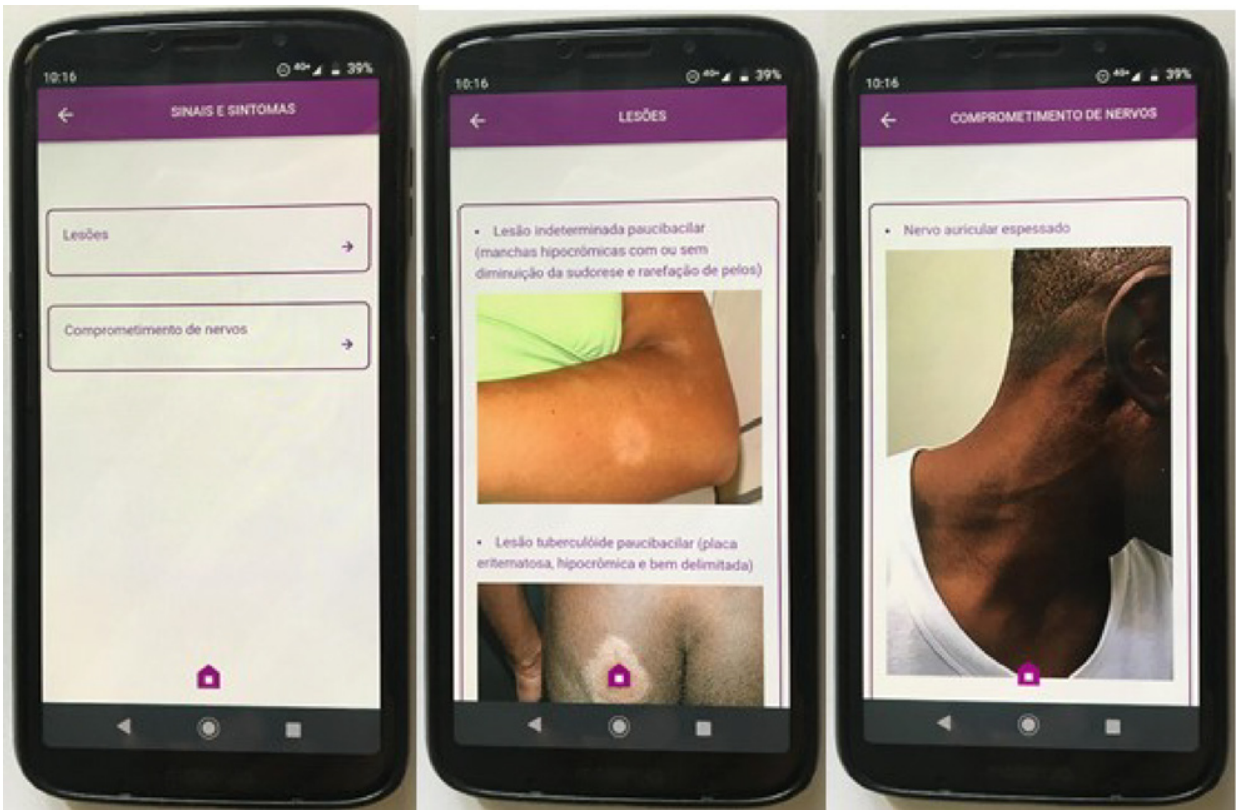

Figure 3. Illustrative image of the screens that make up the section "Signs and symptoms".

2016 onwards, coinciding with the launch of the document "Global Strategy for Leprosy 20162020 ", published by the WHO in the same year. ${ }^{4}$ None of them presented an approach that included the detection of suspected cases among susceptible or communicating individuals.

On the other hand, surveillance of contacts, prevention and early detection of cases is an essential strategy and significant challenge for interrupting the disease's chain of transmission and its elimination. ${ }^{13,14}$

In 2016, the WHO outlined the Global Strategy for Leprosy for the period 2016-2020. Among the strategic actions was the development of national plans to examine all close contacts, especially households. ${ }^{4,15}$

The global strategy's fundamental principles are early detection before the onset of disabilities, immediate treatment, the inclusion of people with the disease, reduction of stigma, the establishment of partnerships, new means of diagnosis, and research, especially aimed at prevention. ${ }^{4}$

The "Hansen's disease" application was developed to be a quick consultation tool and to clarify doubts, mainly about the evaluation of suspected cases of the disease. Its primary focus is to assist in the early detection of the disease, enabling the prevention of disabilities and the disruption of the transmission chain. It contains an intuitive interface. It is easy to handle and consists of brief content, complemented by photos and videos that provide information about the exams for screening symptomatic patients.

Although it has not yet been systematically evaluated, during its construction, some characteristics considered necessary for an application was followed, for example, the usability that takes into account whether the application is easy to install, understand and use. ${ }^{16,17}$ Another characteristic is that it was developed based on scientific research, which guarantees more excellent reliability of the available content. ${ }^{16}$ 


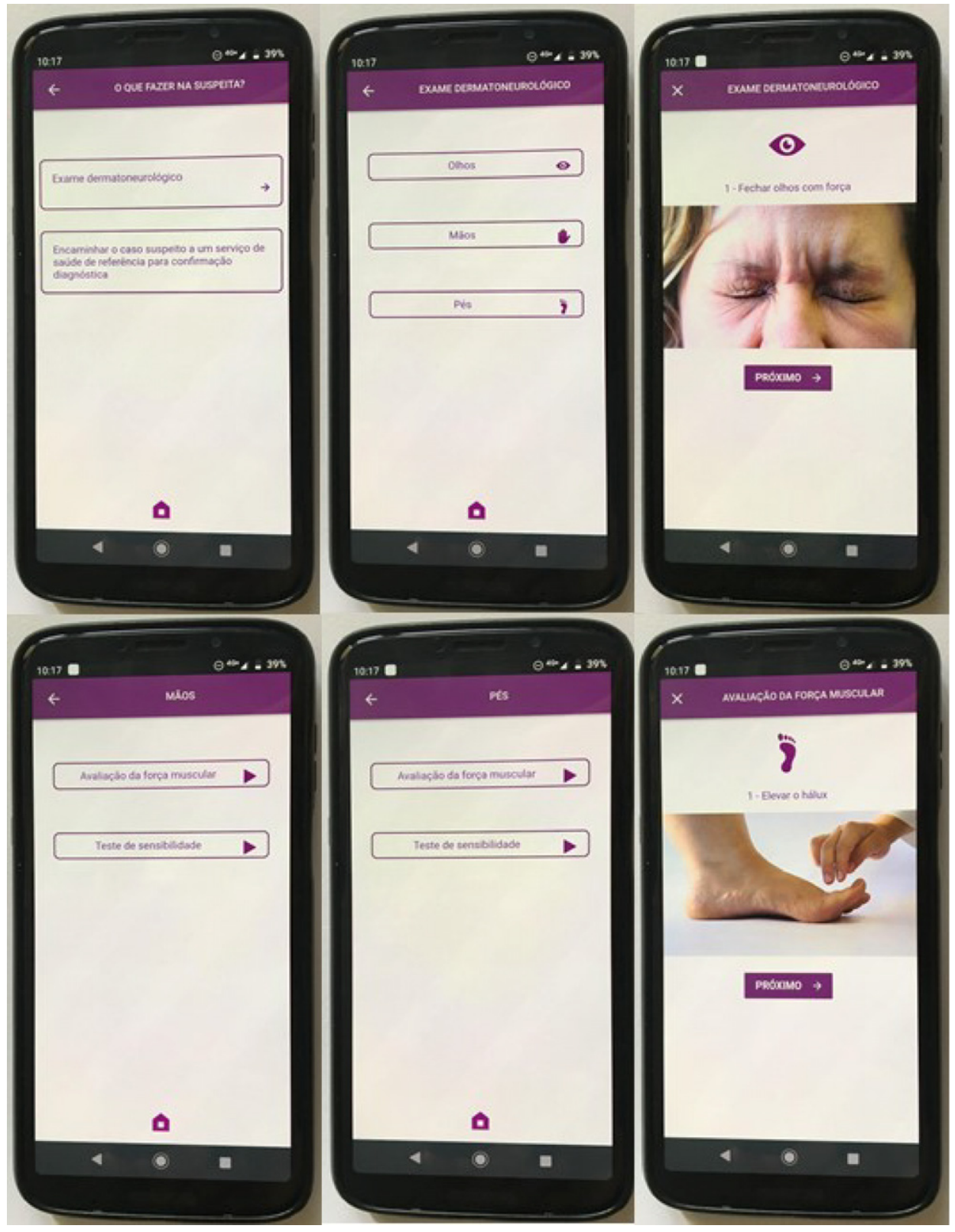

Figure 4. Illustrative image of the screens that make up the section "What to do in case you suspect leprosy?".

The research, which is the final product was the "Hansen's disease" application, used technical materials from the Brazilian Ministry of Health and the WHO to produce written content and videos. The photos depict images of real cases of dermatological lesions and nerve axis involvement. Electronic and communication devices and technologies are a reality that is increasingly present in the daily work of health care professionals and services. According to 
the Global Observatory on e-Health, the number of countries that reported using programmes to access health information increased by $39 \%$ between 2010 and 2015, with those referring to decision support systems representing an increase of $29 \% .{ }^{12}$

Acting in the most diverse contexts, this technological support in health ranges from prevention, monitoring and health promotion actions to diagnosis, interventions, and treatment of already manifested situations. ${ }^{12,18}$

Studies on mobile technologies found that the limitations regarding their use are related to the lack of skill in handling, poor access to the internet, difficulty in seeing the content due to the screen's small size, and the fear of the distance from assistance. ${ }^{17,19}$ According to the same authors, these difficulties can be overcome if incorporating these technologies represents an aid in the day-to-day work, for example, reduction of papers, ease of registration, the possibility of commuting and timesaving. Also, such technologies should not replace the health care professional's performance but rather be a support instrument and act in a complementary way. ${ }^{17,19}$

During the production stages of the "Hansen's disease" application developed using the ADDIE method, there was a concern that it was a clinical support application. When used, it is essential to keep in mind that whatever the content and the possibility of intervention of an application should never be superimposed on the clinical and critical reasoning of health care professionals and, also, distance them from direct contact with people. The next step in developing digital applications for leprosy is to use the fifth evaluation phase of the ADDIE model is endemic leprosy areas.

Given Brazil's territorial extension, the great social inequality and the weaknesses of the health care network, there are countless difficulties in monitoring leprosy and the early detection of new cases to control the disease. Brazil is a large, heterogeneous and unequal country and, although it has been presenting a reduction in leprosy indicators, moving towards the fulfilment of the goals of the Global Strategy for 2020, one must consider the irregular and unequal distribution of resources that determine the different epidemiological situations in the national territory. ${ }^{20}$

Concerning the weaknesses related to the health care network, they are the precarious surveillance of household contacts of leprosy and, when diagnosed, failures in the monitoring and treatment of the disease; irregular and uneven distribution of basic health units; geographical barriers; scarcity of physical and financial resources; control of actions, superficial training on the disease to professionals, among others. For the control and intended eradication of leprosy, it is necessary to invest in services and health professionals, with particular attention to neglected diseases, improving access to services, investing in the continuous qualification of professionals and strengthening the decentralization of the care network. ${ }^{20,21}$

Therefore, it is essential to keep in mind that research and the development of leprosy management technologies are not the right strategies for the control and elimination of the disease. Massive financial investments by government officials in the social areas and the guarantee of rights, especially health, are necessary actions for the global objectives about leprosy to be achieved.

This study's contribution concerns the production of a tool that can support health care professionals in the fight against leprosy, with emphasis on Brazil, and other Portuguesespeaking and/or Spanish-speaking countries, seeing that it is available for both the Android and IOS operating systems.

Our study has some limitations. First, the mobile app did not use the fifth evaluation phase of the ADDIE model in Brazil's leprosy areas. This phase is essential in endemic areas to 
identify suspects of leprosy. The content of the application is still available in Portuguese only. In general, it indicates the referral of suspected cases to the reference health service without mentioning which are these locations. However, this limitation is because the care networks in each region, country and city are heterogeneous.

Also, the application was produced from the funding of a research project. When funding for this specific project is terminated, updates and new versions of the app may be compromised. As future possibilities, further studies may be carried out, developing the Evaluation/Implementation phase of the ADDIE model to evaluate the "Hansen's disease" application.

It is expected that this application will support health care professionals in leprosy control actions, intervening - especially with those communicating confirmed cases to prevent disabilities, eliminate transmission, and achieving the Sustainable Development Goal 3-health and well-being for everyone by 2030 .

\section{Conflict of interests}

The authors declare that there is no conflict of interest.

\section{Authors' contributions}

The first author participated in the design of the project, data collection and analysis. The second and third authors guided all stages of the project and participated in the project's writing and review and the article. The fourth author acted in the review of the project and the article.

\section{Funding}

The study received financial support from the São Paulo Foundation against Hansen's disease and from the Conselho Nacional de Desenvolvimento Científico e Tecnológico/CNPq during the period of $2017 / 2018$.

\section{Patient consent statement}

The Research Ethics Committee approved the School of Nursing study at the University of São Paulo and the Municipal Health Secretariat of São Paulo (opinions 2490,656/2018 and 2801,729/2018) according to the guidelines of the World Medical Association's Declaration of Helsinki.

\section{Acknowledgements}

The authors would like to thank the Division of Clinical Dermatology at the Hospital das Clínicas of the Medical School of USP (Maria Ângela Bianconcini Trindade and João de Magalhães Avancini Ferreira Alves) for their contributions to the technical assistance regarding the production of the application presented here. Also to the Laboratory of Applied Information Technology/UNESP of UNESP (João Vitor Mattos, Carolina Junqueira Ferreira and Daniel Jyoji Nichiata) to develop the technological tool and ES Mídia \& Arte Digital (Evellyn Simon) for the production of the videos.

\section{References}

1 World Health Organization. Global leprosy update, 2018: moving towards a leprosyfree world. Weekly Epidemiological Record. Geneva, 2019; 94: 389-412. Available from: https://apps.who.int/iris/handle/10665/326776. Acessed on 17 November 2020. 
2 Organización Panamericana de la Salud. Iniciativa de la OPS para la eliminación de enfermedades: política para aplicar un enfoque integrado y sostenible de las enfermedades transmisibles en la región de las Américas. Washington; 2019. Available from: https://www.paho.org/es/documentos/iniciativa-ops-para-eliminacion-enfe rmedades-politica-para-aplicar-enfoque-integrado. Acessed on 17 November 2020.

3 Ministério da Saúde, Secretaria de Vigilância em Saúde, Coordenação-Geral de Desenvolvimento da Epidemiologia em Serviços. Guia de vigilância em saúde. Brasília; 2019. Available from: http://portalarquivos2.saude. gov.br/images/pdf/2019/junho/25/guia-vigilancia-saude-volume-unico-3ed.pdf. Accessed on 06 January 2020.

4 World Health Organization. Global leprosy strategy: accelerating towards a leprosy-free world. Geneva, 2016. Available from: https://apps.who.int/iris/handle/10665/254907. Accessed on 06 January 2020.

5 Carvalho R, Foschiani I, Costa M, Marta S, Virmond M. Early detection of M. leprae by qPCR in untreated patients and their contacts: results for nasal swab and palate mucosa scraping. Eur J Clin Microbiol Infect Dis, 2018; 37: 1863-1867. Available from: https://link.springer.com/content/pdf/10.1007/s10096-018-3320-9.pdf. Accessed on 06 January 2020. doi: 10.1007/s10096-018-3320-9.

6 Gagnon M, Ngangue P, Payne-Gagnon J, Desmartis M. M-Health adoption by healthcare professionals: a systematic review. J Am Med Inform Assoc, 2016; 23: 212-220. Available from: https://www.ncbi.nlm.nih.g ov/pubmed/26078410. Accessed on 07 January 2020. doi: 10.1093/jamia/ocv052.

7 Barra D, Paim S, Dal Sasso G, Colla G. Methods for developing mobile apps in health: an integrative review of the literature. Texto Context Enferm, 2017; 26(4): e2260017. Available from: http://www.scielo.br/pdf/tce/v26 n4/en_0104-0707-tce-26-04-e2260017.pdf. Accessed on 07 January 2020. doi: 10.1590/0104-0707201700226 0017.

8 Almomen R, Kaufman D, Alotaibi H, Al-Rowais N, Albeik M, Albattal S. Applying the ADDIE-Analysis, Design, Development, Implementation and Evaluation Instructional design model to continuing professional development for primary care physicians in Saudi Arabia. Int J Clin Med, 2016; 07: 538-5346. Available from: https://www.scirp.org/pdf/IJCM_2016081515041949.pdf. Accessed on 06 January 2020. doi: 10.4236/ijcm.20 16.78059.

9 Barros R. Revisiting knowles and freire: andragogy versus pedagogy—or the dialogic as the essence of sociopedagogic mediation. Educ Pesqui, 2018; 44: e173244. Available from: http://www.scielo.br/pdf/ep/v44/15179702-ep-44-e173244.pdf. Accessed on 06 January 2020. doi: 10.1590/S1678-4634201844173244.

10 Kao CK, Liebovitz DM. Consumer mobile health apps: current state, barriers, and future directions, vol. 9, PM and R. Elsevier Inc., 2017, pp. S106-S115. [Internet]. Available from: https://onlinelibrary.wiley.com/doi/epd f/10.1016/j.pmrj.2017.02.018. Accessed on 07 January 2020. doi: 10.1016/j.pmrj.2017.02.018.

11 Poushter J. Smartphone ownership and internet usage continues to climb in emerging economies, vol. 22, Pew Research Center, 2016. Available from: https://www.pewresearch.org/global/wpcontent/uploads/sites/2/2 016/02/pew_research_center_global_technology_report_final_february_22_2016.pdf. Accessed on 07 January 2020.

12 World Health Organization. Global diffusion of eHealth: making universal health coverage achievable. Report of the third global survey on eHealth. Geneva, 2016. Available from: https://apps.who.int/iris/bitstream/handle /10665/252529/9789241511780eng.pdf;jsessionid=B1083DA67AB905CCD09B6F4E7B8A837C?sequence= 1. Accessed on 07 January 2020.

13 Santos K, Corrêa R, Rolim I, Pascoal L, Ferreira A. Strategies for control and surveillance of leprosy contacts: integrative review. Saúde em Debate, 2019; 43(121): 576-591. Available from: http://www.scielo.br/pdf/sdeb/ v43n121/en_0103-1104-sdeb-43-121-0576.pdf. Accessed on 06 January 2020. doi: 10.1590/0103-110420191 2122 .

14 Bratschi M, Steinmann P, Wickenden A, Gillis T. Current knowledge on Mycobacterium leprae transmission: a systematic literature review. Lepr Rev, 2015; 86(2): 142-155. Available from: https://www.researchgate.net/ publication/281030220_Current_knowledge_on_Mycobacterium_leprae_transmission_A_systematic_literatu re_review. Accessed on 07 January 2020.

15 Ministério da Saúde, Secretaria de Vigilância em Saúde. Caracterização da situação epidemiológica da hanseníase e diferenças por sexo, Brasil, 2012-2016, vol. 49, Brasília, 2018. Available from: http://portalarqu ivos2.saude.gov.br/images/pdf/2018/janeiro/31/2018-004-Hanseniase-publicacao.pdf. Accessed on 06 January 2020.

16 Gomes M, Rodrigues I, Moura N, Bezerra K, Lopes B, Teixeira J et al. Evaluation of mobile apps for health promotion of pregnant women with preeclampsia. Acta Paul Enferm, 2019; 32(3): 275-281. Available from: http://www.scielo.br/pdf/ape/v32n3/en_1982-0194-ape-32-03-0275.pdf. Accessed on 07 January 2020. doi: 10.1590/1982.

17 Rezende L, Santos S, Medeiros A. Assessment of a prototype for the systemization of nursing care on a mobile device. Rev Lat Am Enferm, 2016; 4: 24, e2714. Available from: http://www.scielo.br/pdf/rlae/v24/0104-1169rlae-24-02714.pdf. Accessed on 07 January 2020. doi: 10.1590/1518-8345.0898.2714. 
18 Mendez C, Salum N, Junkes C, Amante L, Mendez C. Mobile educational follow-up application for patients with peripheral arterial disease. Rev Lat Am Enferm, 2019; 27: e3122. Available from: http://www.scielo.br/pd f/rlae/v27/0104-1169-rlae-27e3122.pdf. Accessed on 07 January 2020. doi: 10.1590/1518-8345.2693-3122.

19 Silva A, Mascarenhas V, Araújo S, Machado R, Santos A, Andrade E. Mobile technologies in the nursing area. Rev Bras Enferm, 2018; 71(5): 2719-2727. Available from: http://www.scielo.br/pdf/reben/v71n5/0034-7167reben-71-05-2570.pdf. Accessed on 07 January 2020. doi: 10.1590/0034-7167-2017-0513.

20 Ribeiro M, Silva J, Oliveira S. Epidemiologic study of leprosy in Brazil: reflections on elimination goals. Rev Panam Salud Publica/Pan Am J Public Heal, 2018; 42: e42. Available from: http://iris.paho.org/xmlui/bitstrea $\mathrm{m} /$ handle/123456789/34882/v42e422018.pdf?sequence=1\&isAllowed=y. Accessed on 07 January 2020. doi: 10.26633/RPSP.2018.42.

21 Araujo N, Storer J, Burin E, Fontes M, Arcêncio R, Pieri F. Access regarding leprosy patients in primary health care: potentialities, fragilities and challenges. Hansen Int Hansen outras doenças Infecc, 2016; 41(2): $72-83$. Available from: http://www.ilsl.br/revista/detalhe_artigo.php?id=12781. Accessed on 07 January 2020. 